\title{
Explaining Metropolitan Governance. The Case of Spain
}

\author{
Mariona Tomàs ${ }^{1}$
}

Received: 25 November 2015 / Accepted: 30 September 2016 / Published online: 18 October 2016

(c) Springer-Verlag Berlin Heidelberg 2016

\begin{abstract}
In this paper I examine the characteristics of metropolitan governance in Spain. In the first part, I briefly analyse the different theoretical conceptions and the existing models of metropolitan governance in Europe. I argue that metropolitan governance is explained by the interrelations between the specific institutional context (intergovernmental system) and political culture (attitudes towards metropolitan cooperation). This institutional milieu sets the conditions for the action of political actors and favours the existence of a specific model of metropolitan governance. In the second part, I study the case of Spain, which is interesting for two main reasons. First, it exemplifies well one of the problems of metropolitan governance: the permanent gap between institutions and the process of metropolitanization. Second, in Spain there is a diversity of models of metropolitan governance, which is useful to analyse the reasons for this variation. To do so, I focus on five urban areas (Madrid, Barcelona, Valencia, Bilbao and Sevilla), analysing their models of metropolitan governance and particularly their degree of institutionalization and the type of institutional arrangements that have been made.
\end{abstract}

Keywords Metropolitan governance - Spain · Metropolitanization · Institutions $\cdot$ Local government

Prof. Dr. Mariona Tomàs

marionatomas@ub.edu

Department of Constitutional Law and Political

Science, University of Barcelona, Avda.

Diagonal 690, 08034 Barcelona, Spain

\section{Metropolitan Governance erklären: Das Beispiel Spanien}

Zusammenfassung In diesem Beitrag betrachte ich die Eigenschaften der metropolitanen Governance in Spanien. Im ersten Teil präsentiere ich eine kurze Analyse der verschiedenen theoretischen Konzepte und vorhandener Modelle der metropolitanen Governance in Europa. Die These ist, dass metropolitane Governance sich durch die Verflechtungen zwischen dem spezifischen institutionellen Kontext (intergouvernementales System) und der politischen Kultur (Einstellungen zu metropolitaner Zusammenarbeit) erklären lässt. Dieses institutionelle Milieu setzt den Handlungsrahmen der politischen Akteure und begünstigt das Bestehen eines bestimmten Modells der metropolitanen Governance. Im zweiten Teil untersuche ich das Beispiel Spanien, welches in zweifacher Hinsicht von besonderem Interesse ist. Zum einen wird hier eines der Probleme der metropolitanen Governance deutlich: die dauerhafte Kluft zwischen Institutionen und dem Prozess der Metropolitanisierung. Zum anderen sind in Spanien verschiedene Modelle der metropolitanen Governance vorzufinden. Eine Analyse der Gründe dieser Vielfalt ist erkenntnisreich. Dazu betrachte ich fünf Ballungsräume (Madrid, Barcelona, Valencia, Bilbao und Sevilla) und analysiere deren Modelle der metropolitanen Governance unter besonderer Berücksichtigung des Grads der Institutionalisierung und der Art der institutionellen Vorkehrungen.

Schlüsselwörter Metropolitane Governance $\cdot$ Spanien · Metropolitanisierung · Institutionen · Lokale Regierung 


\section{Introduction}

The $20^{\text {th }}$ century has witnessed a transformation of the European territory. The first half of the century saw the consolidation of the urbanization process, leading, after the 1950 s, to a progressive phenomenon of suburbanization. At the end of the century the process culminated in territorial metropolitanization, spreading the limits of the 'urban' (Moriconi-Ebrard 1993). Indeed, the limits of what we understand to be 'urban' have widened, and nearly three-quarters of the European population currently live in metropolitan and urban areas (Eurostat 2014: 26). But these limits continue to extend and are in constant evolution, resulting in multiple statistical definitions of the 'urban' (e.g. metropolitan areas, metropolitan regions, urban areas, cityregions). Without entering into a strict statistical definition, we understand metropolitan areas and urban agglomerations (treated here as synonyms) as territories with a minimum population (according to Eurostat 2014: 15: 250,000 inhabitants) with one or more main centres characterized by labour market integration and activities (economical, cultural, leisure) provided by the mobility of the inhabitants.

The challenges posed by the metropolitan phenomena are diverse: social (combating inequalities, ensuring access to public services), economic and financial (guaranteeing competitiveness and efficiency), territorial and environmental (the management of urban explosion, mobility and waste), political and institutional (the co-ordination of policies and services, democratic representation). In this article I focus on the last question: how to govern metropolitan areas? What are the models of metropolitan governance and how can their differences be explained? This is a recurrent topic not only in the field of urban politics and urban studies but also in the political agenda (Lefèvre 2009; Savitch/ Vogel 2009).

This article is structured as follows. In the first part, I briefly analyse the different theoretical conceptions and the existing models of metropolitan governance in Europe. In the second part, I focus on a case study: Spain. This is an interesting case for two main reasons. First, it illustrates well one of the problems of metropolitan governance: the permanent gap between institutions and the process of metropolitanization. Second, in Spain there is a diversity of models of metropolitan governance, which is useful to analyse the reasons for this variation. The last section is the conclusion summarizing the main results.

\section{Governing Metropolitan Areas}

The permanent gap between traditional administrative boundaries and metropolitan territories has led to several theoretical approaches and proposals concerning the ideal model for the government of urban agglomerations (for an overview see Lefèvre 1998; Brenner 2002; Heinelt/ Kübler 2005; Lefèvre 2009; Savitch/Vogel 2009). Each approach supports alternative forms of metropolitan governance (institutional reforms, inter-municipal competition and flexible arrangements) to pursue different normative goals (efficiency, democracy, equality and economic competitiveness) on different scales (local and metropolitan).

From the reform school perspective, the metropolitan area is a single political unit that requires one integrated government for the entire metropolitan area (one-tier after amalgamations or a two-tier metropolitan structure). Megacities or metropolitan governments are responsible for redistributive policies and for ensuring equal access to public goods and services, in addition to promoting efficiency in the delivery of services and improving the quality of local democracy (Sharpe 1995). In contrast, authors embracing public choice theory consider metropolitan areas as fragmented spaces. From their perspective, competition among small units of governments ensures greater efficiency and democracy (Bish/Ostrom 1973). Considering the metropolitan area as a market, people choose their place of residence according to their preferences (Tiebout 1956). Unlike the reformers, the authors of the public choice school consider that small governments are the right scale and cooperation should not be compulsory: municipalities can voluntarily cooperate, if necessary. In the context of globalization and the internationalization of the economy, the new regionalism appears as an alternative conception of metropolitan governance (Savitch/ Vogel 2000). In contrast to the previous approaches, the regionalists argue that metropolitan areas are made up of interdependent municipalities and other public and private actors who must cooperate to address common problems. Instead of creating megacities, flexible arrangements that include a plurality of actors are the best way to promote economic competitiveness and to deal with social inequalities and urban sprawl (Swanstrom 2001). For instance, strategic planning is a tool of public-private cooperation that establishes a shared long-term vision of metropolitan challenges (Tomàs 2011: 296). The move from government to governance can be an opportunity or a threat for local democracy, depending on the degree of transparency and accountability in public-private arrangements (Kübler/ Wälti 2001).

Four metropolitan governance models can be portrayed according to their degree of institutionalization, that is, depending on the type of institutional arrangements that have been made. These models are: metropolitan governments, metropolitan agencies, vertical co-ordination and horizontal 
collaboration (Tomàs 2015a). ${ }^{1}$ At one extreme, metropolitan governments are structures explicitly created to face metropolitan challenges. According to the reformist principles, these structures rely on a directly elected metropolitan council, exclusive competences and funding established by law, representing the maximum expression of metropolitan political recognition. However, the European examples of metropolitan governments do not meet these conditions, either because they share responsibilities with higher-level government institutions (Lisbon), because they depend on the funding of higher authorities (London, Stuttgart) or because they are indirectly elected (Barcelona). Metropolitan agencies are the second type of arrangements. In contrast to metropolitan governments, they are given the competence to manage or plan one sole service (e.g. public transport, environment, police). In most countries in Europe, we find agencies for the planning or/and delivery of one service (the most common are transport, waste management, water, fire and emergency services). In the United Kingdom, this was the formula used after the removal of existing metropolitan authorities in the 1980s (like in Birmingham, where there are three different metropolitan bodies for transport, police and fire services).

The third model is that of vertical co-ordination, in which metropolitan policies are not made by a specific metropolitan institution but de facto by other already existing levels of government (e. g. a region, a province, a county), for example, intermediate governments like the Stockholm County, the Region Hovedstaden (in Copenhagen) or the regional government of Madrid (Comunidad de Madrid). These institutions were not created to administer this metropolitan function but they exercise it in practice. Finally, the less institutionalized models of horizontal collaboration are based on voluntary cooperation between municipalities and other public and private actors. In this case, the initiative is local and its existence does not involve reforms in existing political structures. The most traditional form is that of a Union or Association of Municipalities, like in Wroclaw (Poland). In contrast, strategic planning involves a plurality of actors (municipalities but also other institutions, chambers of commerce, trade unions, universities, associations), like in Torino (Italy) through the association Torino Strategica. In the case of horizontal collaboration, capacity for action in terms of competencies and funding will depend on the legal framework in which the partnership is located as well as the capacity of representatives to agree on collective decisions.

It must be said that these models are idealistic types and set general trends. In reality, some approaches are mixed and models that in theory are the same, in practice

\footnotetext{
1 The examples given in Section 2 are based on the results of comparative research on European models of metropolitan governance. For details see Tomàs (2015a).
}

are different. Elements that are more intangible, related to political culture and to the attitudes and values of local representatives towards metropolitan governance, influence the final model. For example, in some countries there is a greater tradition of institutionalizing metropolitan cooperation through the creation of new structures (such as in France), whilst in others reforms move towards the reduction of the number of structures (such as in Denmark). In certain countries reforms are made at the national level and homogeneous models are sought (such as currently in Italy), whilst in other countries there is a large variety of governance models (such as in Germany). The political and legal status of the municipality has also an effect: whether it is an important government level (with competences and funding), whether it has a main role in the country's politics (high levels of participation in municipal elections), etc. Finally, the failures and successes of various governance formulas can be understood by considering the attitudes of metropolitan representatives: the willingness to co-operate and find a common denominator in favour of the general interest. These cultural and institutional factors that shape models of metropolitan governance are known as the "institutional milieu" (DiGaetano/Strom 2003: 363), that is, "the complexes of formal and informal political and governmental arrangements that mediate interactions among the structural context, political culture, and political actors" (DiGaetano/Strom 2003: 363). In other words, and following the work of other authors (Pierre 1999; Mossberger/Stoker 2001), I think that the diversity of models of metropolitan governance is explained by the interrelations between the specific institutional context (intergovernmental system) and political culture (attitudes towards metropolitan cooperation).

To sum up, we cannot talk of a single European model of metropolitan governance. There is a great diversity, as a result of the traditions and historical richness of the different countries. Spain is an example of a country with a rich history and internal differentiation. Studying metropolitan governance in this case helps us to understand the factors shaping metropolitan governance and the importance of institutions.

\section{Metropolitan Governance in Spain}

\section{1 "The Metropolitan" in Spain}

Today, Spain has an urban society in a preponderantly rural territory: the densely populated urban areas on the coast and in Madrid contrast with a pattern of lower density development in the central zones of the country. Indeed, there are thirteen cities with more than 300,000 inhabitants, whereas more than $85 \%$ of the municipalities have less than 5000 
Table 1 Most populated urban areas in Spain (more than 500,000 inhabitants)

\begin{tabular}{ll}
\hline & Population (2014) \\
\hline Madrid & $6,007,424$ \\
Barcelona & $5,028,221$ \\
Valencia & $1,541,356$ \\
Sevilla & $1,303,370$ \\
Malaga & 959,898 \\
Bilbao & 904,607 \\
Asturias & 823,979 \\
Zaragoza & 740,926 \\
Alicante-Elche & 695,225 \\
Murcia & 643,916 \\
Bahia de Cádiz & 642,784 \\
Vigo & 587,066 \\
Palmas Gran Canaria & 540,190 \\
Palma de Mallorca & 539,424 \\
Granada & 524,044 \\
\hline
\end{tabular}

Source: http://atlasau.fomento.gob.es (June 10, 2016)

inhabitants. ${ }^{2}$ Unlike countries such as the United States or Canada, there is no systematic statistical definition to define metropolitan areas in Spain. In fact, the National Institute of Statistics does not have a metropolitan data classification category; nor is one provided by most of the regional statistical institutes ${ }^{3}$. To establish the major metropolitan areas in Spain, one must refer to academic studies or institutional initiatives such as the Digital Atlas of Urban Areas in Spain from the Ministry of Development. Similarly to the definition of urban regions in Europe (Tomàs 2015b), in Spain there are alternative definitions of 'the metropolitan', with the extent and number of municipalities changing according to the specific agency or institution. Being aware of the plurality of definitions of the metropolitan phenomenon, Table 1 shows the list of the most populated urban areas in Spain (more than 500,000 inhabitants) based on the data of Digital Atlas of the Urban Areas in Spain.

Despite evidence of a metropolitanization process, the Spanish political system has not responded to this phenomenon (Alba/Navarro 2005). The Spanish Constitution of 1978 establishes that the State is territorially organized into three levels of government: the central government, the regional tier or the Comunidades Autónomas (CCAA), and the local tier (formed by 8114 municipalities and 50 provinces). The municipality is the basis of all territorial organization, and the first level of the citizen's participation in public affairs. The municipality is ruled

\footnotetext{
${ }^{2}$ See http://atlas.vivienda.es (September 13, 2016).

${ }^{3}$ In Andalusia, the Institute of Statistics refers to "urban agglomeration" as a polycentric urban area forming a single market for residence and work (Almoguera Sallent 2008: 30).
}

and administered by the council that is made up of directly elected councillors and a mayor who is elected by the councillors. The province is the second tier of local administration and is indirectly elected. It gives assistance to municipalities through local networks and programs.

The law regulating local government stipulates that municipalities have the right to associate freely in the form of inter-municipal associations (mancomunidades) and consortia (consorcios) (article 44 of the law regulating local government). Following the Napoleonic model of local government (Hesse/Sharpe 1991), inter-municipal cooperation is a very popular choice in all regions and is used mainly for pooling services in small municipalities. In the last 30 years, the number of inter-municipal associations has kept growing: from 109 in 1986 to 996 associations in 2015 (according to the Register of Local Entities from the Ministry of Public Administration 2015: 15).

Concerning the metropolitan scale, the law regulating local government establishes that the CCAA are responsible for creating, modifying and abolishing metropolitan areas by their own Statutes of Autonomy (article 43 of the law regulating local government). The central government has not given incentives to the creation of metropolitan areas. The Large Cities Law on Measures for the Modernization of Local Government, approved in 2003, aimed at modernizing the management council and the development of citizen participation in large cities. This law recognizes that large cities share some particularities, but does not address metropolitan problems. In 2006, the cities of Madrid and Barcelona were given special status as the biggest Spanish cities. However, in these two special laws there are no references to or dispositions regarding the metropolitan scale. In sum, governing metropolitan areas is a decentralized competence that, a priori, should open the door to the existence of a plurality of models of metropolitan governance, as in federal states such as Germany (Heinelt/ Zimmermann 2011).

In the next section I analyse the models of metropolitan governance in five Spanish agglomerations: Madrid, Barcelona, Valencia, Sevilla and Bilbao. They are the biggest urban areas (apart from Malaga) and they represent different geographic Spanish regions, that is, five different CCAA with diverse regulations concerning metropolitan 
governance. ${ }^{4}$ To what extent is there a diversity or homogeneity of models? How can their differences or similarities be explained?

\subsection{A Variety of Models}

To analyse metropolitan governance in these five Spanish agglomerations, I will classify them in relation to the models described in the previous section, that is, according to their degree of institutionalization (from more to less): metropolitan governments, metropolitan agencies, vertical co-ordination and horizontal collaboration.

In Spain, the metropolitan area of Barcelona is one with a greater degree of institutionalization. In July 2010, the Parliament of Catalonia approved the Law of the Metropoli$\tan$ Area of Barcelona (MAB). The MAB is the urban core of the large urban area and accounts for almost $60 \%$ of its population. It holds 3.2 million inhabitants and $36 \mathrm{mu}-$ nicipalities (Tomàs 2015a: 5); most of them are immediately contiguous and some cities are physically adjacent to Barcelona and connected by the subway. Formed by a council of 90 members (delegates from municipalities according to their population), the MAB is funded by transfers (mainly from municipalities) and by taxes (on waste and sewage). The responsibilities of the MAB include territory and urbanism, transport and mobility, housing, environment, economic development and social cohesion. As provided by law, the entry into force of the MAB meant the disappearance of the three metropolitan authorities that had existed since the 1980s: the Metropolitan Transport Entity (covering 18 municipalities), the Metropolitan Entity of Water and Waste Treatment (33 municipalities) and the Association of Municipalities of the Metropolitan Area (23 municipalities). These entities were created in 1987 when the Barcelona Metropolitan Corporation - a metropolitan body for urban planning - was abolished by the regional government.

The MAB cannot be defined as an ideal model of metropolitan government. Indeed, it is indirectly elected, has little fiscal autonomy and its competences are not ex-

\footnotetext{
4 This work is based on the results of two consecutive projects. The first one (Exploring Urban Policies, EXNURB) analysed the development of urban policies in the most populated Spanish cities from 1979 to 2007, while the second project (Urban policies and resilience, POLURB) focused on the effects of the economic crisis on urban policies (from 2008 to 2014). In the case of Andalusia, Sevilla (and not Malaga) the urban agglomeration was chosen because it is the biggest urban area and the capital of the Autonomous Community. Quantitative and qualitative methods were used, combining documental analysis, the construction of vulnerability indicators in cities and the transcription and Atlas-Ti analysis of 20 semi-structured interviews with the main stakeholders of each city. Both projects were funded by the Spanish Ministry of Science: EXNURB (CSO2008-04173/CPOL) (2008-2011) and POLURB (CSO2011-28850) (2011-2014).
}

clusive but shared both by local and regional governments. Moreover, the MAB has to live with other sectorial agencies, associations and consortiums existing in the MAB, such as the Metropolitan Transport Authority (MTA). Created in 1997, the MTA is responsible for coordination and transport planning on a larger scale (253 municipalities). In contrast, the MAB has jurisdiction over the first ring of municipalities, a narrow definition of the metropolitan phenomenon. However, in the Spanish context, it is the only case of a metropolitan authority with several competences and a tradition of stable inter-municipal cooperation since the end of the 1970s. ${ }^{5}$ This cooperation at the metropolitan scale has been fostered by the drawing up of a Strategic Plan since the beginning of the 2000s. The City of Barcelona had previously developed a model for cooperation between public and private actors resulting in the development of three strategic plans (1990, 1994 and 1999). In 2000, it was for the first time applied at a larger scale, the metropolitan area. Thus, political representatives of 36 municipalities in the metropolitan area, along with other representatives of public institutions and civil society, developed a voluntary exercise to build consensus on the future of the metropolis. The first Metropolitan Strategic Plan was approved in 2003, the second in 2010. Although the recommendations of the Strategic Plan are only indicative, this exercise made the unity of the metropolitan area visible and represented a first step towards the end of partisan disagreements. Indeed, the adoption of the law on the MAB had the support of all parliamentary groups after 30 years of disputes and political rivalries between the municipalities of the metropolitan area and between the area and the regional government. Nowadays, the Strategic Plan is still a platform for debate but has a minor role.

Following the classification in terms of the degree of institutionalization, in Valencia there are three metropolitan sectorial agencies: the Metropolitan Water Services (formed by 51 municipalities), the Metropolitan Waste Treatment (formed by 45 municipalities) and the Public Metropolitan Transportation (60 municipalities). This last entity develops the Metropolitan Plan of Transport of Valencia, including integrated fare management and administrative services. It works with other transport agencies (Railways of the Generalitat Valenciana and Municipal Transport Company) and the Valencian Metropolitan Mobility Authority. The three agencies are governed by

\footnotetext{
5 In Galicia (north-eastern region), a law creating the metropolitan area of Vigo was approved in 2012 by the regional parliament. According to the law, it is an indirectly elected body comprising 14 municipalities, with several competencies (economic development, public transport, environment, water, waste management, land-use planning, tourism and cultural promotion). Although this law was approved in 2012, it has never been executed, mainly due to political divergences between the members of the urban agglomeration.
} 
indirectly elected representatives of the municipalities, according to their population. This situation of institutional fragmentation has only existed since 2001. In 1946, the Gran Valencia Metropolitan Corporation was created for planning purposes. In 1986, it was transformed into the Consell Metropolità de l'Horta, which became a metropolitan government with competencies on transport and spatial planning, water and sewage. However, similarly to the Barcelona case, it was eliminated in 1999 by the regional government and replaced in 2001 by the three separate agencies. In short, today the metropolitan area of Valencia is institutionally organized by sectoral agencies covering a different number of municipalities. The metropolitan dimension is recognized and metropolitan agencies manage some metropolitan essential services (transport, waste, water). However, a common understanding of the metropolitan reality does not exist, since each agency covers a different territory. Moreover, the relationship between the City of Valencia and some of the metropolitan municipalities has been characterized by political conflicts, which has not helped to build a shared metropolitan vision.

In the case of Bilbao there is also an intermediate degree of institutionalization, with metropolitan sectorial agencies and also vertical coordination by the regional and provincial governments. The Corporation of Greater Bilbao, created in 1945, was abolished by the Basque Parliament in 1980 . The Basque Government and the metropolitan municipalities assumed all its powers. For the provision of services, there are two agencies of transport and water. The Biscay Transport Consortium, created in 1975, was created with the aim of building the Bilbao metro and managing public transport in 10 municipalities, with responsibility for coordinating fares and mobility. It is financed both by the regional and provincial governments. The other metropolitan agency is the Bilbao Bizkaia Water Consortium, which was created in 1967 and enlarged in 1995 for the provision, treatment and delivery of water. Currently, the Bilbao Bizkaia Water Consortium is a public body providing comprehensive services of water supply and sanitation to 72 municipalities, representing $90 \%$ of the population of the Province of Bizkaia.

It is worth mentioning another agency, Bilbao Ria 2000, created for the renovation of Bilbao and its estuary ('the Guggenheim reform'). Created in 1992 and with representatives from all levels of government (central, regional, provincial and the municipalities of Bilbao and Barakaldo), this agency coordinates and implements various activities that integrate planning, transport and the environment. The agency is one of the actors taking part in the process of strategic planning of Bilbao, executed mainly through Bilbao Metropolis-30, a public-private partnership created in 1991, and with the collaboration of regional, provincial and municipal governments. Like the entity in Barcelona, the strategic plan mobilizes especially the most organized groups (institutions, public organizations, universities, trade unions, business associations) so as to raise a debate on shared future challenges. To sum up, in Bilbao there is not a comprehensive metropolitan institution but several sectoral agencies, in which local (first and second-tier) but also regional governments participate. As we have seen in Valencia, each agency covers a different number of municipalities.

In the case of Madrid and Sevilla we find a model of vertical coordination, where regional governments mainly assume the metropolitan responsibilities. In both cases, regional governments have created metropolitan agencies to deal with one service.

In Madrid, during the dictatorship a wave of annexations between 1948 and 1954 shaped the modern city. Indeed, 13 municipalities were annexed to the central city, which achieved an area larger than 600 square kilometres (equivalent to the Metropolitan Area of Barcelona). Similarly to other cities, the Commission for Planning and Coordination of the Madrid metropolitan area (COPLACO) was created during the dictatorship to deal with regional planning. The Comunidad de Madrid (CAM), the regional government, assumed its functions when it was created in 1983. Taking into account that there was just one province in the territory, this local administration was dissolved and its powers went to the CAM. Therefore, the CAM is formed by the regional government and 179 municipalities. There are no other supramunicipal entities (like counties) in a context where the City of Madrid, which is both the regional capital and the capital of Spain, gathers in half of the total population of the CAM. In 2003, the Law on Local Government of Madrid recognized the possibility of creating metropoli$\tan$ areas when necessary (article 76). However, there has not been any initiative to institutionalize metropolitan areas because of the regional leadership in metropolitan affairs (Rodríguez Álvarez 2002). Indeed, the limits of the urban area of Madrid are similar to those of the regional government (179 municipalities).

In practice, the CAM, with an assembly directly elected by the citizens and its own resources, coordinates major metropolitan policies, such as transport. For this purpose the Regional Consortium of Transport was created in 1986, bringing together all public and private organizations related to public transport and ensuring coordination of services and the integration of fares of the public transport system of the CAM. Metro de Madrid, SA, the public company that manages the Madrid metro network, is also part of the Consortium. Besides, the company Canal de Isabel II is responsible for the entire water cycle in virtually all municipalities of the CAM. To sum up, in the case of Madrid there has been no need to create metropolitan structures since the 
Table 2 Degree of institutionalization of metropolitan governance (from more to less)

\begin{tabular}{ll}
\hline Urban area & Degree of institutionalization \\
\hline Barcelona & Metropolitan government (36 municipalities), metropolitan agency of transport (253 municipalities), strategic \\
& planning (36 municipalities and other public and private actors) \\
Valencia & Metropolitan agencies of transport (60 municipalities), water (51 municipalities) and waste (45 municipalities) \\
Bilbao & Metropolitan agencies of transport (10 municipalities) and water (72 municipalities), strategic planning (33 munic- \\
& ipalities and other public and private actors) \\
Madrid & Vertical coordination and regional agencies of transport and water (179 municipalities) \\
Sevilla & Vertical coordination and metropolitan agencies of transport (44 municipalities), water (12 municipalities) and \\
& housing (27 municipalities)
\end{tabular}

regional government has assumed this role and has taken charge of the main metropolitan policies (transport, water).

Finally, in Sevilla there is also an important regional role in managing issues at the metropolitan level, especially in transport. Sevilla is the largest agglomeration of the south of Spain and the capital of Andalusia. In 2001 the regional government created the Metropolitan Consortium of Transport, with the participation of the Government of Andalusia, the Provincial Government and 44 municipalities in the area. The Government of Andalusia also manages the metro of Sevilla, with a clear metropolitan vocation. Besides, there are other agencies with metropolitan character, like EMASESA, the municipal water company of Sevilla, founded in 1974 and servicing 12 municipalities. In 2006, the Housing Consortium of the Sevilla Area was created: it includes regional and 27 local governments, although with very limited responsibilities. In the case of Sevilla, there is no consensus on the definition of the limits of the metropolitan area. There are different studies and management plans that include a variable number of municipalities. The Spatial Plan of the Urban Agglomeration of Sevilla (POTAUS), approved in 2009, distinguishes between the first and second metropolitan rings and includes 46 municipalities. This means an area of 4900 square kilometres, in which 1,421,000 inhabitants live, corresponding to the limits of the metropolitan area (Almoguera Sallent 2008: 28). However, as we have seen, the Consortium of Transport covers 44 municipalities while the Housing Consortium includes 27 and that of water supply only 12 . Again, we see a gap between the territorial definition of the metropolitan area and the institutional arrangements.

To sum up, in these five urban areas we find a variety of models of metropolitan governance, ranging from the most institutionalized model (Barcelona) to models with an intermediate degree of institutionalization (see Table 2).

As we have seen, these are mixed models. For instance, in Barcelona and Bilbao the metropolitan government and the metropolitan agencies coexist with horizontal collaboration (strategic planning). In the next section I explore the reasons for the variety of models as well as the shared aspects. Following my reasoning, it is essential to under- stand the 'institutional milieu' where metropolitan governance takes place.

\subsection{Explaining Metropolitan Governance}

According to DiGateano and Strom (2003), as well as other authors embracing neo-institutionalism like Pierre (1999), both formal and informal institutions shape the models of metropolitan governance and explain their differences. This institutional milieu, including the institutional system as well as the political culture, sets the rules for the interrelations of groups of actors, as the Spanish case shows.

The models of metropolitan governance analysed in this article are definitely influenced by the intergovernmental system. Spain has been a decentralized country since the 1980s, where three levels of government have to be taken into account: the central, the regional and the local level. In this period of democratization, the process of decentralization has clearly moved from the central towards the regional level. For instance, the share of expenditure and the percentage of public workers show a gain on the regional level at the expense of the central government, while in the case of local government the figures have remained stable over the last 30 years $(20 \%$ of total public workers and $13 \%$ of total public expenditure) (Espasa Queralt/ Bosch Roca 2006: 108). The different cases share this general setting, where regional governments have been reluctant to give power to urban agglomerations. Moreover, municipalities themselves have also been jealous of their autonomy and suspicious of the metropolitan bodies. This was especially true during the 1980s, when (in all the cases except for Sevilla) the Corporaciones metropolitanas created during the dictatorship were sooner or later abolished and replaced, in some cases, by sectorial agencies. The abolition was carried out by the new regional governments and was particularly polemic in Barcelona and Valencia. 30 years later, only in Barcelona is there a light version of a metropolitan government, while the rest of the urban agglomerations are governed by sectoral agencies or directly by the regional governments.

Other institutional factors shape metropolitan governance. As we have seen, Spanish regulation establishes 
a general framework of local government and then allows each Autonomous Community to regulate the creation of other supramunicipal institutions like metropolitan areas. In other words, specific legislation on the issue is necessarily regional, while the central government determines general legislation (e.g. law on local financial resources, law on local government). This may explain why there is not an official statistical definition of 'the metropolitan' in Spain: it is considered a regional affair. If we compare the different legislation of each Autonomous Community where the five urban agglomerations exist, we find one main difference. In the statutes of three CCAA there is recognition of the possibility of creating metropolitan areas by a regional law (article 93 in Catalonia, article 65 in Comunitat Valenciana, article 94 in Andalusia). In contrast, in the statutes of Madrid and the Basque Country there are no references to the creation of metropolitan areas. These references are to be found in their respective legislation on local government: the law of 2003 in the case of Madrid (article 76) and the law of 2016 in the Basque Country (article 108). To sum up, the degree of institutionalization of metropolitan governance depends on the regional parliaments, which have scarcely used this prerogative.

Another difference linked to the institutional system refers to the complex interrelations between the central government and the CCAA. These asymmetrical relationships have been extensively analysed (Aja 2007; Moreno 2008) and have historical roots. Analysing metropolitan governance cannot be understood without taking into account the position of each Autonomous Community within the Spanish State. For instance, the competition between Barcelona as the capital of Catalonia and Madrid as the capital of the State may explain the annexations by Madrid during the dictatorship, which were not allowed in Barcelona.

Other institutional factors affect the model of metropoli$\tan$ governance, for instance, the degree of political fragmentation. Firstly, there are differences depending on the number of existing administrations and institutions in the metropolitan area. Indeed, there are agglomerations characterized by a high level of fragmentation and others in which there is more institutional simplicity. For example, in Barcelona and Valencia there are the municipalities, the province and the counties (supramunicipal structures of cooperation created by regional governments). Each structure is governed by local representatives according to the result of municipal elections. The situation is otherwise in Madrid where there is only the regional government and $179 \mathrm{mu}-$ nicipalities, with no other supramunicipal structures. In this case, the leadership of the regional government in urban affairs is evident, although it has not been exempt from political tensions.
However, political systems are not just the sum of their formal institutional structures. Political institutions in each urban agglomeration are linked together by informal arrangements and political culture, that is, the system of values, symbols, and beliefs that give meaning to social and political organization and action (DiGateano/Strom 2003: 370). As these authors have shown, political culture acts as a framework providing meaning and legitimacy for political actors. The symbolic dimension is then another important issue in metropolitan governance. Is there a shared view on metropolitan governance? Metropolitan narratives are part of the social process of metropolitan governance, where different actors have their own definition of the urban area: ideas on nature, landscape, the built environment, culture/ ethnicity, dialects, economic success/recession, periphery/ centre relations, stereotypic images of people/community (Paasi 2003: 477). The analysis of how narratives are constructed is inevitably linked to the power relations existing within an urban agglomeration. There might be a dominant narrative or competing narratives, depending on the configuration of local actors and the interrelations between public and private actors.

In the case of the Spanish metropolitan areas examined in this article, we find a diversity of portraits. In Barcelona and Bilbao there is a metropolitan debate favoured by the existence of strategic plans at this scale. In both cases, it has been possible to build a shared metropolitan vision with the collaboration of representatives from local institutions and other public and private actors. In spite of the existence of a fragmented institutional landscape, attitudes have evolved to favour metropolitan cooperation, which has led, in the case of Barcelona, to the approval of a law creating a new metropolitan government with the support of all political parties (Tomàs 2011). The success of metropolitan projects such as the Barcelona Olympic Games in 1992 and the 'Guggenheim reform' in Bilbao, also at the beginning of the 1990s, may have helped to build this consensus. In contrast, the Universal exposition of 1992 in Sevilla, the Formula 1 in Valencia or the three failed candidatures for the Olympic Games in Madrid were focused in the central city and did not succeed in building a shared vision of the urban agglomeration. Moreover, in Sevilla, Valencia and Madrid strategic plans have not reached the metropolitan dimension. Unlike the Basque and Catalan examples, recommendations to convene a forum of mayors or other similar initiatives have not been implemented. In other words, there is no metropolitan narrative shared by the diverse groups of actors. Indeed, the model of metropolitan growth has been controversial and criticized by environmental and neighbourhood associations in the three cities. While in Barcelona and Bilbao there are also tensions between actors regarding specific projects, it has been possible to build cooperation that ensures a least common denominator. 


\section{Conclusions}

In this article I have analysed the main characteristics of metropolitan governance in Spain, focusing on five cities and analysing their models of metropolitan governance. Four metropolitan governance models can be described according to their degree of institutionalization, that is, depending on the type of institutional arrangements that have been made: metropolitan governments, metropolitan agencies, vertical co-ordination and horizontal collaboration. On average, in Spain there is a medium degree of institutionalization: examples of metropolitan governments (Barcelona) or a lack of cooperation are exceptional. What is more usual is the existence of sectorial metropolitan agencies (Valencia, Bilbao) and/or coordination by another level of government (Sevilla, Madrid). As we have seen in the examples, different institutions and agencies coexist in the urban areas, usually covering a disparate number of municipalities, even in the case of maximum institutionalization. In Barcelona, in spite of the existence of a metropolitan government (the Metropolitan Area of Barcelona), another agency covering a larger territory exists (the Metropolitan Authority of Transport).

I argue that the institutional milieu (both formal institutional arrangements and informal arrangements) explains these differences. In this case, one of the main factors explaining metropolitan governance is the model of State and the way it has been implemented. The process of democratization in the late 1970s and early 1980s progressed in parallel to the process of decentralization. In the Spanish Constitution, regional governments were given the power to create and abolish metropolitan structures, while there is no national policy on urban affairs. An official definition of a metropolitan area is lacking: in each case different concepts (area, region, etc.) are used, implying a greater or lesser number of municipalities.

Moreover, the growth in size and importance of metropolitan areas has occurred in parallel with regional development and the action of the first democratic councils. Indeed, the building of the new democratic state was based on the newly created regional governments and the local governments, institutions that needed to form their own legitimacy. In this context, regional and municipal policies leave little space for metropolitan policies, and the metropolitan scale has frequently been used as an object of partisan struggles (e. g. Barcelona, Valencia). In other cases, the central city is reluctant to build a metropolitan vision (e.g. Sevilla and Madrid). In the context of the creation of new legitimacies and leaderships both from regional and local governments, there is no place for a metropolitan legitimacy. Similarly to the Canadian case, a strong metropolitan level seems one level too many (Sancton 2001: 547). Indeed, a shared metropolitan vision has only been built in Barcelona and Bilbao.

In 2018, 40 years will have passed since the approval of the Spanish Constitution after almost four decades of dictatorship. Regional governments have been established and their competences have been reinforced. However, local governments have been unsuccessful in their bids for a second decentralization to increase their powers and resources. A future scenario of municipal reform could be an opportunity to diminish the context of institutional fragmentation in the majority of urban agglomerations and to reinforce the metropolitan dimension of policies.

\section{References}

Aja, E. (2007): El Estado Autonómico. Federalismo y hechos diferenciales. Madrid.

Alba, C.; Navarro, C. (2005): Metropolitan Areas in Spain, a diverse and unknown reality. In: Hoffmann-Martinot, V.; Sellers, J. (eds.): Metropolitanization and Political Change. Wiesbaden, 265-293.

Almoguera Sallent, M.P. (2008): La Ciudad cambia de escala: Sevilla Metropolitana. Sevilla.

Bish, R.L.; Ostrom, V. (1973): Understanding Urban Government. Metropolitan Reform Reconsidered. Washington, D.C.

Espasa Queralt, M.; Bosch Roca, N. (2006): La hisenda local a la Unió europea (UE-15). Barcelona.

Brenner, N. (2002): Decoding the newest "Metropolitan Regionalism" in the USA: A critical overview. In: Cities 19, 1, 3-21.

DiGaetano, A.; Strom, E. (2003): Comparative Urban Governance: An Integrated Approach. In: Urban Affairs Review 38, 3, 356-395.

Eurostat (2014): Eurostat Regional Yearbook 2014. Luxembourg.

Heinelt, H.; Kübler, D. (eds.) (2005): Metropolitan governance. Capacity, democracy and the dynamics of place. London.

Heinelt, H.; Zimmermann, K. (2011): How Can We Explain Diversity in Metropolitan Governance within a Country? Some Reflections on Recent Developments in Germany. In: International Journal of Urban and Regional Research 35, 6, 1175-1192.

Hesse, J.J.; Sharpe, L.J. (1991): Local government in international perspective: some comparative observations. In: Hesse, J.J. (ed.): Local government and urban affairs in international perspective. Baden-Baden, 603-621.

Kübler, D.; Wälti, S. (2001): Metropolitan governance and democracy: how to evaluate new tendencies? In: McLaverty, P. (ed.): Public participation and innovations in community governance. Aldershot, 115-140.

Lefèvre, C. (1998): Metropolitan government and governance in western countries: A critical review. In: International Journal of Urban and Regional Research 22, 1, 9-25.

Lefèvre, C. (2009): Gouverner les métropoles. Paris.

Ministry of Public Administration (2015): Register of Local Entities. Madrid.

Moreno, L. (2008): La federalización de España. Poder político y territorio. Madrid.

Moriconi-Ebrard, F. (1993): L'urbanisation du monde depuis 1950. Paris.

Mossberger, K.; Stoker, G. (2001): The Evolution of Urban Regime Theory. The Challenge of Conceptualization. In: Urban Affairs Review 36, 6, 810-835.

Paasi, A. (2003): Region and Place: Regional Identity in Question. In: Progress in Human Geography 27, 4, 475-485.

Pierre, J. (1999): Models of urban governance. The institutional dimension of urban politics. In: Urban Affairs Review 34, 3, 372396. 
Rodríguez Álvarez, J.M. (2002): Madrid: le pilotage politique par la région. In: Jouve, B.; Lefèvre, C. (eds.): Métropoles ingouvernables. Paris, 107-124.

Sancton, A. (2001): Canadian Cities and the New Regionalism. In: Journal of Urban Affairs 23, 5, 543-555.

Savitch, H.V.; Vogel, R.K. (2000): Paths to new regionalism. In: State and Local Government Review 32, 3, 158-168.

Savitch, H.V.; Vogel, R.K. (2009): Regionalism and urban politics. In: Davies, J.S.; Imbroscio, D.L. (eds.): Theories of urban politics. London, 106-124.

Sharpe, L.J. (ed.) (1995): The Government of World Cities: the Future of the Metro Model. London.
Swanstrom, T. (2001): What we argue about when we argue about regionalism. In: Journal of Urban Affairs 23, 5, 479-496.

Tiebout, C.M. (1956): A pure theory of local expenditures. In: Journal of Political Economy 64, 5, 416-424.

Tomàs, M. (2011): La escala metropolitana: un análisis transversal. In: Iglesias, M.; Martí-Costa, M.; Subirats, J.; Tomàs, M. (eds.): Políticas urbanas en Espana. Grandes ciudades, actores y gobiernos locales. Barcelona, 283-306.

Tomàs, M. (2015a): Metropolitan governance in Europe: Challenges and Models. Barcelona.

Tomàs, M. (2015b): If urban regions are the answer, what is the question? Thoughts on the European experience. In: International Journal of Urban and Regional Research 39, 2, 382-389. 